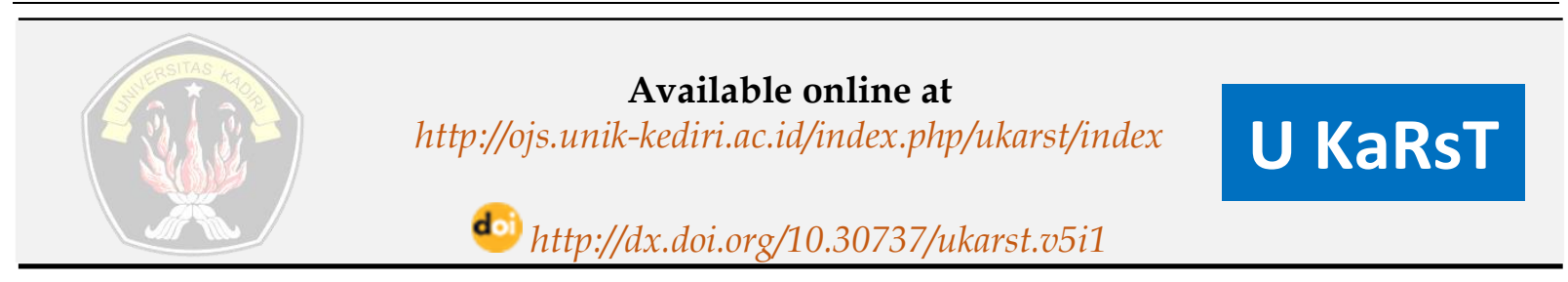

\title{
Study of Anisotropy Characteristics of Bogor Volcanic Soil
}

\author{
Y. Sulastri ${ }^{1 *}$, P. P. Rahardjo ${ }^{2}$. \\ $1^{*}$ Departemen of Civil Engineering, Parahyangan Catholic University. \\ ${ }^{2}$ Lecturer in Departemen of Civil Engineering, Parahyangan Catholic University. \\ Email: ${ }^{1 *}$ yusi.three@gmail.com
}

\begin{tabular}{|c|c|}
\hline \multicolumn{2}{|l|}{ Article History : } \\
\hline Article entry & $06-10-2020$ \\
\hline Article revised & $14-10-2020$ \\
\hline Article received & $19-01-2021$ \\
\hline
\end{tabular}

Keywords :

Anisotropy, Compaction Static, Compressibility, Strength.

IEEE Style citing this article : [14] R. L. and C. W. C. Parfitt, "Estimation of forms of $\mathrm{Fe}$ and Al: a review and analysis of contrasting soils by dissolution and Moessbauer methods, " Aust. J. Soil Res., no. 26, pp. 121-144, 2018

\section{Introduction}

Volcanic soils cover $1 \%$ of the Earth's surface yet support $10 \%$ of the world's population, including some of the highest human population densities. This is usually associated with their high natural fertility [1]. However, this is true only in part. Such Soil represents an area of the Earth's surface replenished with new minerals escaping from Earth's interior. [2]. However, some deep magmatic processes lead to an imbalance of volcanic soil parent materials elements that can impact plants and animals' health growing in or on them. In contrast, all other soils express various stages of the degradation (weathering) of these minerals.

Volcanic soils cover more than 124 million hectares of the Earth's surface. The significant volcanic soils in the Pacific, where oceanic plate subduction, produces extensive 
rhyolitic and andesitic volcanism [1]. Major areas of volcanic soils occur in Chile, Peru, Ecuador, Colombia, Central America, the United States, Kamchatka, Japan, the Philippines, Indonesia, New Zealand, and the independent island states of the southwest Pacific. Basaltic volcanism dominates the Pacific, Indian and Atlantic oceans islands, where the new lithosphere is added to the existing plate to penetrate the hot mantle like in Hawaii. [3].

Anisotropy results in the Soil from the deposition process can describe soil grains' characteristics or those caused by the effects of stresses generated during deposition and subsequent erosion [3]. All soils behave in general anisotropy, and some exhibit undrained shear strength. The latter phenomenon shows anisotropy for changes in the effective shear strength parameter with the direction used in the shear stresses [2][4]. The undrained shear strength of soft soil anisotropy was given by Bjerrum, Ladd, et al., And Jamiolkowski et al. The anisotropy undrained shear strength in NC was more significant at lower plasticity values [5][6].

The same undrained direct shear strength for vertical sample orientation shifted with the horizontal test orientation, and the specimen is tested horizontally[7]. This study uses London soil with samples taken at a tilt orientation of $30^{\circ}$ from the horizontal direction [8]. The sample was then reconsolidated and tested with an unconfined compression test. The shear strength obtained was $28 \%$ smaller than the samples taken with a vertical orientation [9]. The carried out research on London soil was carried out with vertically and horizontally oriented samples. The results obtained from horizontal samples are 15 - 39\% stronger [10].

This is consistent with the research results where the ratio of horizontal stress to vertical stress is between $1.5-2.5$ at a depth of $30 \mathrm{~m}$ on London soil [11]. A series of tests on San Francisco soil. The sample test used the unconsolidated test with the TX-CU. This test under anisotropy and isotropy conditions. The results showed that samples under anisotropy conditions were $10 \%$ stronger than samples under isotropy conditions. [12].

From the data, 42 locations were tested by triaxial under anisotropy and isotropy conditions. The results obtained are undrained normalized shear strength. With effective soil pressure at anisotropy conditions between $75 \%$ - 100\% compared to isotropy conditions. [13], testing with the Cuboidal Shear Device. The samples used were kaolin and a mixture of consolidated silt. Obtained the anisotropy ratio (Suh / Suv) between 0.68 - 2.00 [14].

Another test with Simple Direct Shear at Boston Blue Clay. The results show that the anisotropy conditions of soil shear strength at various slope orientations have different values [15]. In the work field, there are many anisotropy conditions found. So it is necessary to do a lot of research to learn it. One example is an illustration of anisotropy's presence in the shear 
strength of undried Soil [11]. Taking the Duncan field's slope model shows the anisotropy of the undrained soil shear strength along the possible slip circle. The shear strength value will change along with slip according to tilt orientation, and this study aims to know the anisotropy characteristics of Bogor Volcanic Soil.

\section{Research Method}

This study conducted two tests, namely the first field testing with original soil samples in the form of CPTu and dilatometer. The CPTu test's objective is to determine the vertical soil parameters, while the dilatometer is to determine the horizontal soil parameters. The second is laboratory testing with compacted soil samples through Index properties, Triaxial UU, and consolidation testing. Sampling test in sharing the orientation of the tilt angle of $0^{\circ}$ and $90^{\circ}$ [9]. From the triaxial test results, the strength parameters are c and phi. Simultaneously, for consolidation in the laboratory, the compression index $\left(\mathrm{C}_{c}\right)$ and the vertical direction coefficient of consolidation $\left(\mathrm{C}_{\mathrm{v}}\right)$ were obtained.

\subsection{Description and Technical}

Figure 1 shows the compaction scheme in the field.

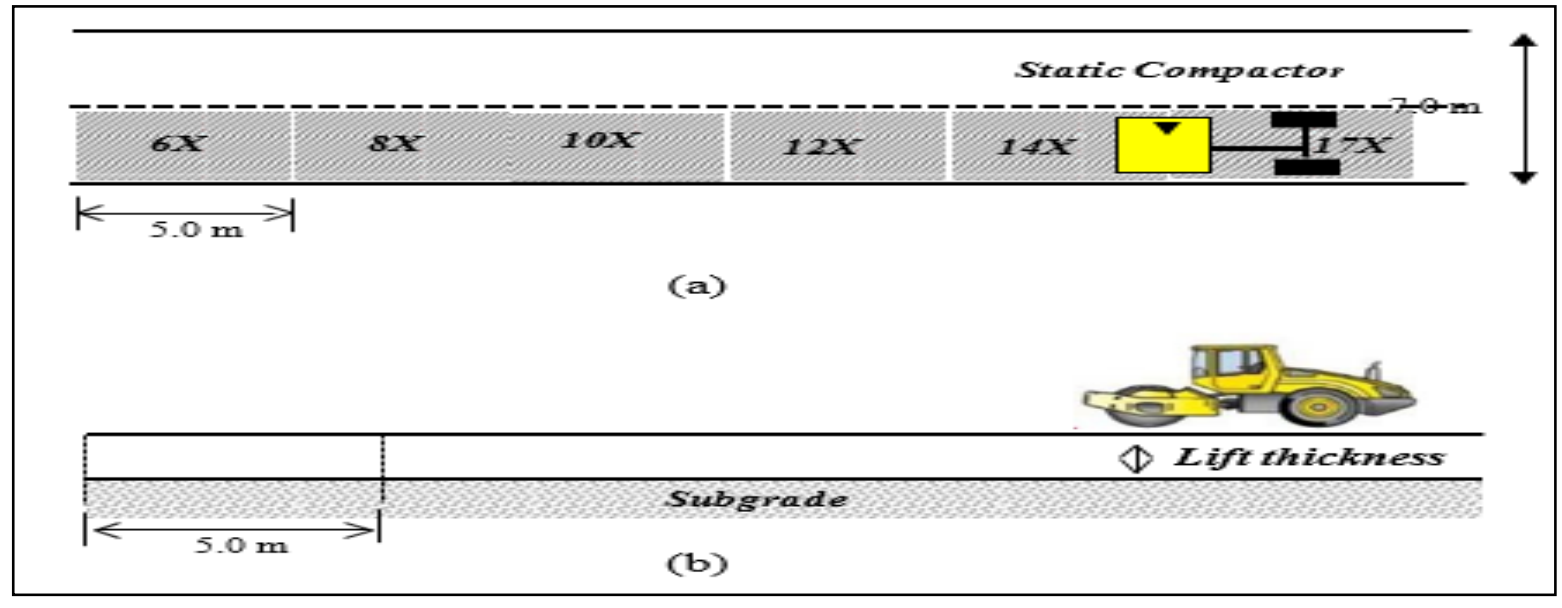

Figure 1. Field Compaction

From Figure 1a, the compaction scheme is carried out in the field using compaction techniques on several blocks with a length of $5 \mathrm{~m}$ each. In Figure $1 \mathrm{~b}$, compaction was do by lifting the thickness of the static compactor layer.

\subsection{Sampling Technique}

The Soil to be tested is volcanic Soil taken from Lido Theme Park's tourist area Bogor. Soil samples taken were undisturbed Soil, including original soil samples one tube, field compacted soil samples six-block samples with the type of compaction $6 \mathrm{x}, 8 \mathrm{x}, 10 \mathrm{x}, 12 \mathrm{x}, 14 \mathrm{x}$, and $17 \mathrm{x}$. 


\subsection{Data Analysis Technique}

Tests do on compacted Soil by testing Fill Weight, Moisture Content, Specific Gravity, Atterberg Limits, Sieve and Hydrometric Analysis, Triaxial UU with $0^{\circ}$ and $90^{\circ}$ tilt orientation, and Consolidation Test with $0^{\circ}$ and $90^{\circ}$ slope orientation. The tests do at the Laboratory of Soil Mechanics, Department of Civil Engineering, Parahyangan Catholic University.

The tests carried out are below.

1. The Fill Weight is very useful in evaluating volcanic Soil, namely the ratio between soil weight and volume in the field's original state.

2. The water content test determines a soil sample's moisture content, namely the ratio between water weight and dry Soil's weight.

3. The specific gravity test includes determining the Soil's density using a pycnometer bottle, Soil that must pass the No. sieve. 40.

4. The Atterberg limit test determines the soil sample's liquid limit, plastic limit, and plasticity index.

5. The sieve analysis test aims to determine the percentage of soil sample grain size used.

6. A hydrometer test is needed to obtain the percentage value of fine-grained Soil in the sample.

7. Triaxial Test UU

8. Consolidation must be testing to obtain pre-consolidation pressure, consolidation coefficient in the vertical and horizontal direction, and soil compression coefficient.

\subsection{Definition of Variable Operations}

\subsubsection{CPTu}

The Cone Penetration Test (CPT) in Indonesia is gaining popularity because of its ease of use and generally consistent test results. However, the mechanical ponder test cannot measure the resistance of the tip of the sondir in very soft soils [16][17]. The development of the electronic sondir test has also received great attention. With the addition of a pore water pressure sensor, this test can better predict soil parameters and provide continuous soil profiles as a field test tool. This electronic sondir test accompanied by measuring pore water pressure is then known as the CPTU or Piezocone Penetrometer Test.

Introduced in 1970 in Indonesia, the piezo-cone test became known more generally in 1990 [18]. The piezo-cone test results' interpretation includes predictions of soil behavior type, undrained shear strength and drained shear strength, stress history, compressibility, soil 
permeability, and consolidation coefficient. On soft soils undergoing consolidation (under consolidating), the CPTU test can estimate the degree of consolidation and identify the soil layer that is currently consolidating [5].

\subsubsection{Dilatometer}

The pressure readings- $\mathrm{A}$ and $\mathrm{B}$ in the field must be corrected for membrane stiffness, the initial reading of the manometer, and the filler pins' elevation to determine the pressure $\mathrm{P}_{0}$ and $\mathrm{P}_{1}$ using the following formula below.

$P_{0}=1.05\left(A-Z_{M}+\Delta A\right)-0.05\left(B-Z_{M}-\Delta B\right)$

$P_{1} \quad=B-Z_{M}-\Delta B$

Where :

$\Delta \mathrm{A}, \Delta \mathrm{B}=$ correction value obtained from membrane calibration

$\mathrm{ZM}=$ initial reading of the manometer at atmospheric pressure

The corrected stresses, namely P0 and P1, are then used to become A and B values in interpreting. The correlation was obtained by calibrating the DMT results with good parameters. Most of these correlations form the basis of current interpretations [19]. Interpretation is developed by first determining three parameters of DMT, namely:

1. Material index, $\mathrm{I}_{\mathrm{D}}$

2. Horizontal stress index, $K_{D}$

3. Modulus of the dilatometer, $E_{D}$

\section{Results and Discussions}

\subsection{Result Laboratory Soil Compaction}

The results of compaction testing in the field, soil samples are tested in the laboratory by testing including index properties. These include content weight, moisture content, specific gravity, atterberg limits, sieve, and hydrometric analysis and engineering properties, including the Triaxial and Consolidation Law with an orientation slope of $0^{\circ}$ and $90^{\circ}$. In Figure 2, the results of the test. 


\begin{tabular}{|c|c|c|c|c|c|c|c|c|}
\hline \multicolumn{9}{|c|}{ Resume of Laboratory Testing Results } \\
\hline \multicolumn{2}{|c|}{ Sample No. } & & & $6 x$ & $8 X$ & $10 \mathrm{X}$ & $12 X$ & $14 X$ \\
\hline \multicolumn{4}{|c|}{ Depth } & $0.00-0.20 \mathrm{M}$ & $0.00-0.20 \mathrm{M}$ & $0.00-0.20 \mathrm{M}$ & $0.00-0.20 \mathrm{M}$ & $0.00-0.20 \mathrm{M}$ \\
\hline \multicolumn{2}{|c|}{ Indek Properties } & symbol & unit & & & & & \\
\hline 1. & Fill Weight & $\gamma$ & $t / m^{3}$ & 1,540 & 1,598 & 1,602 & 1,433 & 1,548 \\
\hline 2. & Moisture Content & $\omega$ & $\%$ & 48,02 & 52,45 & 50,56 & 48,05 & 46,73 \\
\hline \multirow[t]{4}{*}{3.} & Specific Gravity & Gs & - & 2,44 & 2,44 & 2,59 & 2,41 & 2,46 \\
\hline & Void Ratio & e & - & 1,35 & 1,33 & 1,44 & 1,49 & 1,34 \\
\hline & Porosity & $n$ & - & 0,57 & 0,57 & 0,59 & 0,60 & 0,57 \\
\hline & Degree of saturation & $\mathrm{Sr}$ & $\%$ & 86,99 & 96,32 & 91,23 & 77,73 & 86,21 \\
\hline
\end{tabular}

Figure 2. Resume of Laboratory Test

\subsubsection{Grain Size Analysis}

The filter and hydrometer tests on $6 x, 8 x, 10 x, 12 x, 14 x$, and $17 x$ ground samples. Based on the grading test results, graphs show that there are two groups of soil types. The first group is black shading with a relatively uniform gradient size with a grain size of $0.01 \mathrm{~mm}$, namely the silt's dominant type. The second group odometer with a yellow shading color, namely the dominant type of clay.

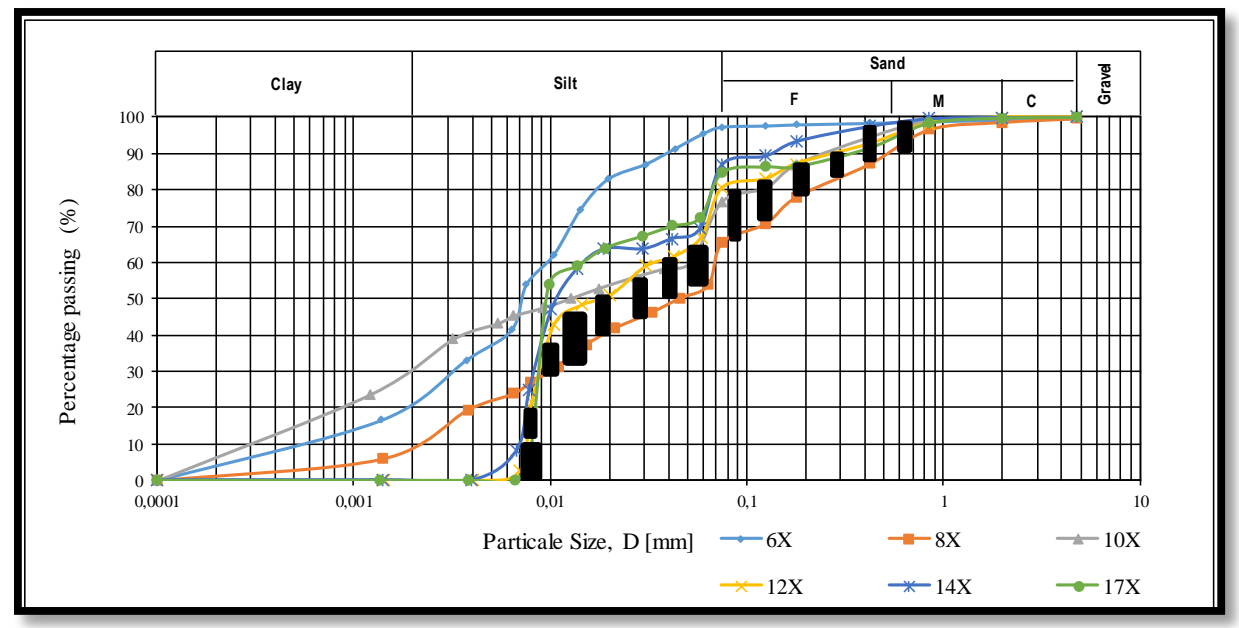




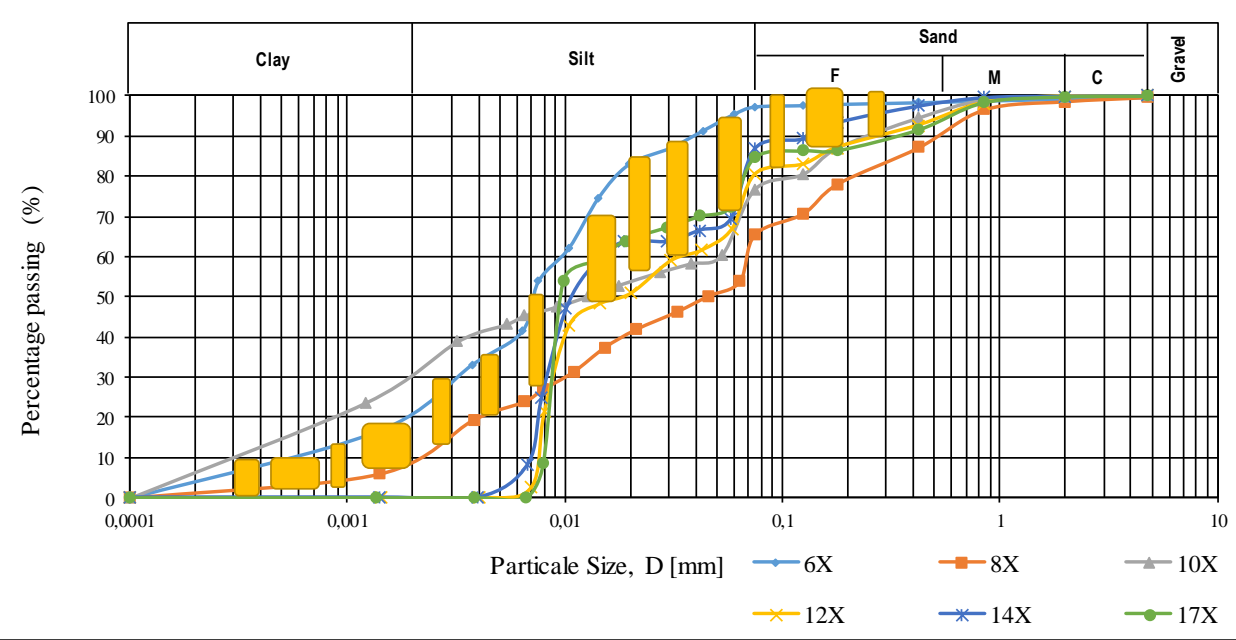

Figure 3. Grain Size Analysis

\subsubsection{Atterberg Limit}

Limits and plasticity indexes test on $6 x, 8 x, 10 x, 12 x, 14 x$, and 17x ground samples (Table 1 Results of Atterberg limits test). In Figure 4, the Cassagrande Chart shows that the soil classification is in the ML and MH areas, which are Allophan soil types, according to Wesley in Figure 4. Figure 5 Number of Rolls - LL, and IP show that more grinding will affect soil behavior. The number of rolls - LL and PL indicates that the more turns, the LL and IP values are higher [20][21].

Fine-grained soil characteristics depend on Atterberg boundaries and natural water content. Figure 4 and Figure 5 show the distribution of the cavity ratio, moisture content, Atterberg Limit, Liquidity Index, and Plasticity - depth index based on laboratory tests. As shown in the figure below, the water content distribution is generally between the plastic limit and the liquid limit and the Soil in its plastic state [22]. Meanwhile, the value of the void ratio varies between $1.7-1.2$ in Table 1. Consistent data are obtained, with a decreasing ratio with soil depth. The ratio decreases with soil depth.

Table 1. Results of Void Ratio

\begin{tabular}{|l|c|c|c|c|c|c|c|}
\hline \multirow{2}{*}{ Index Properties } & \multirow{2}{*}{ symbol } & \multirow{2}{*}{ unit } & \multicolumn{5}{|c|}{ Sample No. } \\
\cline { 4 - 8 } & & & $\mathbf{6 X}$ & $\mathbf{8 X}$ & $\mathbf{1 0 X}$ & $\mathbf{1 2 X}$ & $\mathbf{1 4 X}$ \\
\hline Void Ratio & $\mathrm{e}$ & - & 1.35 & 1.33 & 1.44 & 1.49 & 1.34 \\
\hline
\end{tabular}

Source : Laboratory Testing of the Department of Civil Engineering, Parahyangan Catholic University. 
Table 2. Results of Atterberg limits test

\begin{tabular}{cccccccc}
\hline & \multicolumn{7}{c}{ Compaction (X) } \\
\cline { 2 - 7 } & $\mathbf{6}$ & $\mathbf{8}$ & $\mathbf{1 0}$ & $\mathbf{1 2}$ & $\mathbf{1 4}$ & $\mathbf{1 7}$ \\
\hline Liquid Limit (LL or $\boldsymbol{w}_{\mathbf{L}}$ ) (\%): & 65 & 71 & 41 & 47 & 47 & 49 \\
\hline Plastic Limit (PL or $\left.\boldsymbol{w}_{\boldsymbol{P}}\right)(\boldsymbol{\%}):$ & 56 & 53 & 30 & 34 & 35 & 37 \\
\hline Plasticity Index $(\mathbf{P I})(\boldsymbol{\%}):$ & 9 & 18 & 11 & 13 & 12 & 12
\end{tabular}

Source: Laboratory Testing of the Department of Civil Engineering, Parahyangan Catholic University.

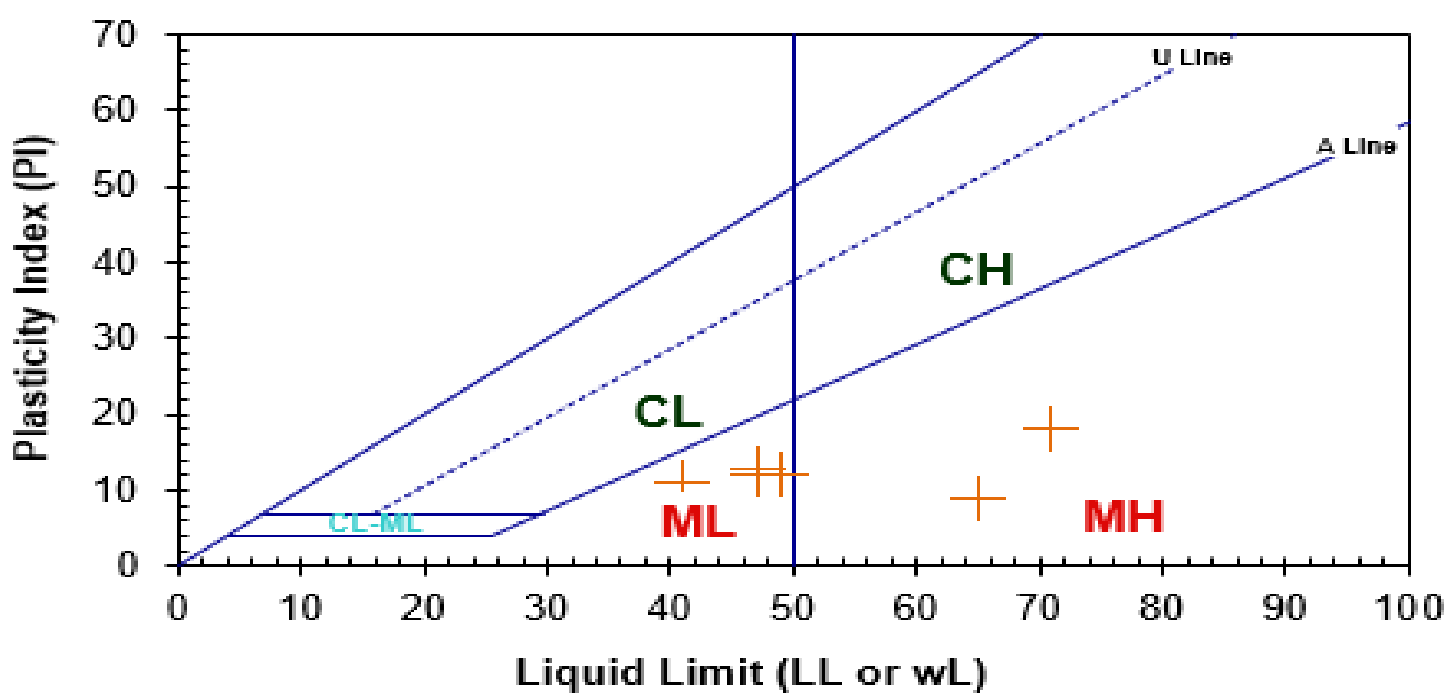

Figure 4. Casagrande Chart

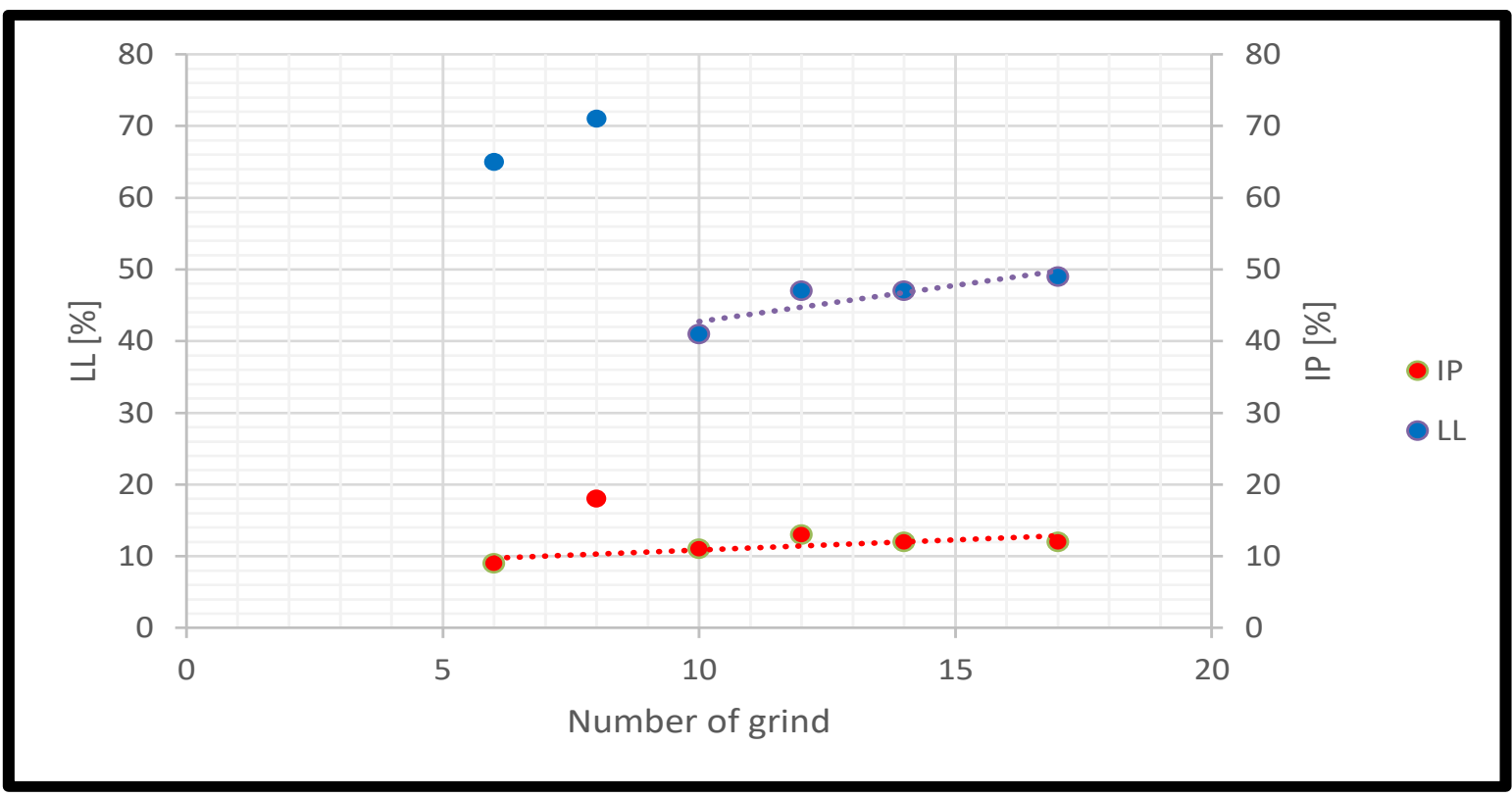

Figure 5. Compaction, LL, and IP 
Liquid Limit and Soil Plasticity Index were carried out on 6x, 8x, 10x, 12x, 14x, and 17x ground samples. The Casagrande chart shows that the soil classification is in the ML and MH areas, which are Allophan's soil types, according to Wesley, 2010. The number of mills LL and IP indicates that the more crushed land will affect soil behavior. The number of grinds - LL and PL indicate that the more grinding, the LL and IP values are higher.

\subsubsection{Triaxial Unconsolidated Undrained (UU)}

Figure 6 shows that for volcanic soils, more grinding will affect the value of the inner shear angle to increase, while in cohesion (c), more grinding on the Soil will affect c, which remains or decreases.

Table 3. Results of Triaxial Unconsolidated Undrained

\begin{tabular}{ccccc}
\hline Compaction & $\mathrm{C}_{\text {Horizontal }}$ & $\mathrm{C}_{\text {Vertical }}$ & $\emptyset_{\text {Horizontal }}$ & $\emptyset_{\text {Vertical }}$ \\
\hline$(\mathrm{X})$ & $\mathrm{kg} / \mathrm{cm}^{2}$ & $\mathrm{~kg} / \mathrm{cm}^{2}$ & $\circ$ & ${ }^{\circ}$ \\
\hline 6 & 0.43 & 0.52 & 10.75 & 17.44 \\
\hline 8 & 0.38 & 0.17 & 17.97 & 23.52 \\
\hline 10 & 0.36 & 0.33 & 27.96 & 17.29 \\
\hline 12 & 0.22 & 0.25 & 19.32 & 18.37 \\
\hline 14 & 0.09 & 0.07 & 25.22 & 39.78
\end{tabular}

Source: Laboratory Testing of the Department of Civil Engineering, Parahyangan Catholic University.
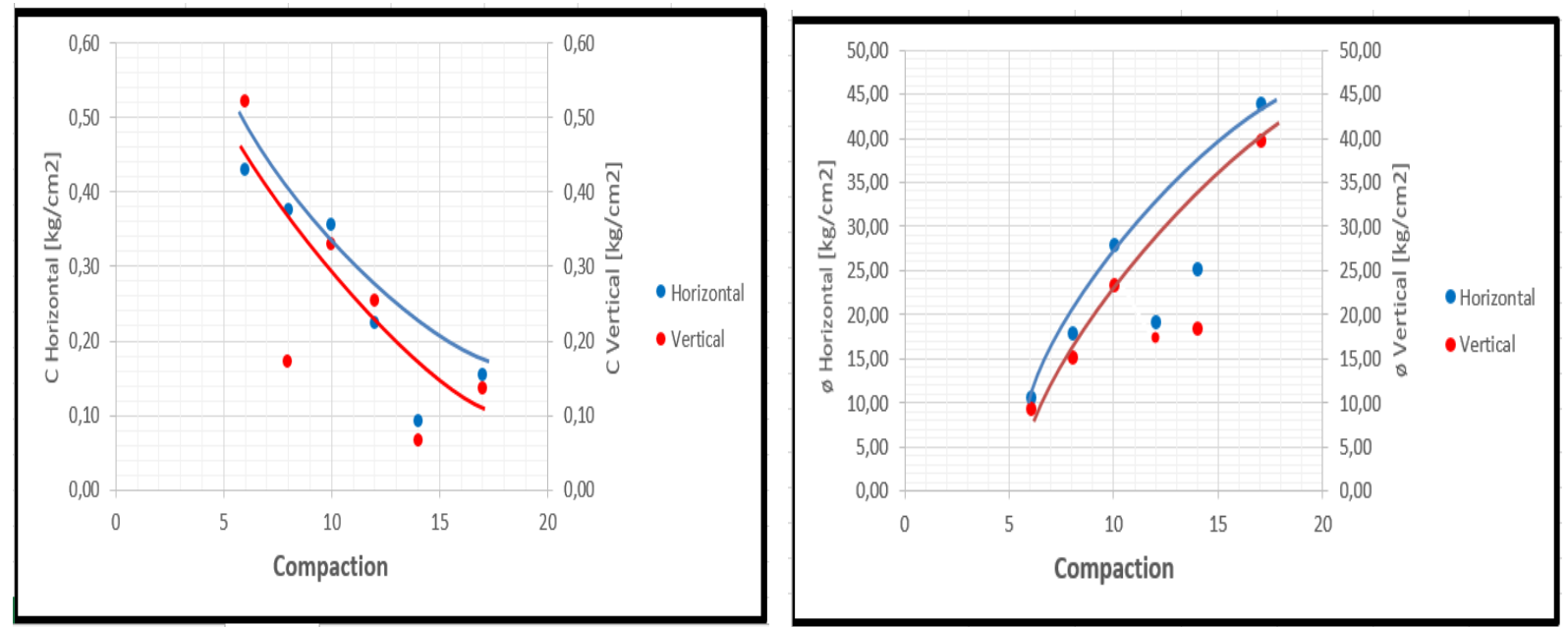

Figure 6. Compaction, $\varnothing_{\text {Horizontal, }}$ and $\emptyset_{\text {Vertical }}$ 
The graph shows that for volcanic Soil, more rubbing will affect the value of the inner shear angle to increase, while in cohesion (c), more rubbing on the Soil will affect $\mathrm{c}$, which is constant or decreases.

Based on the calculations in Figure 6, this volcanic soil sample shows anisotropic properties.

$C_{\text {Horizontal }}=1,3 C_{\text {Vertical }}$

$\emptyset_{\text {Horizontal }}=\varnothing_{\text {Vertical }}$
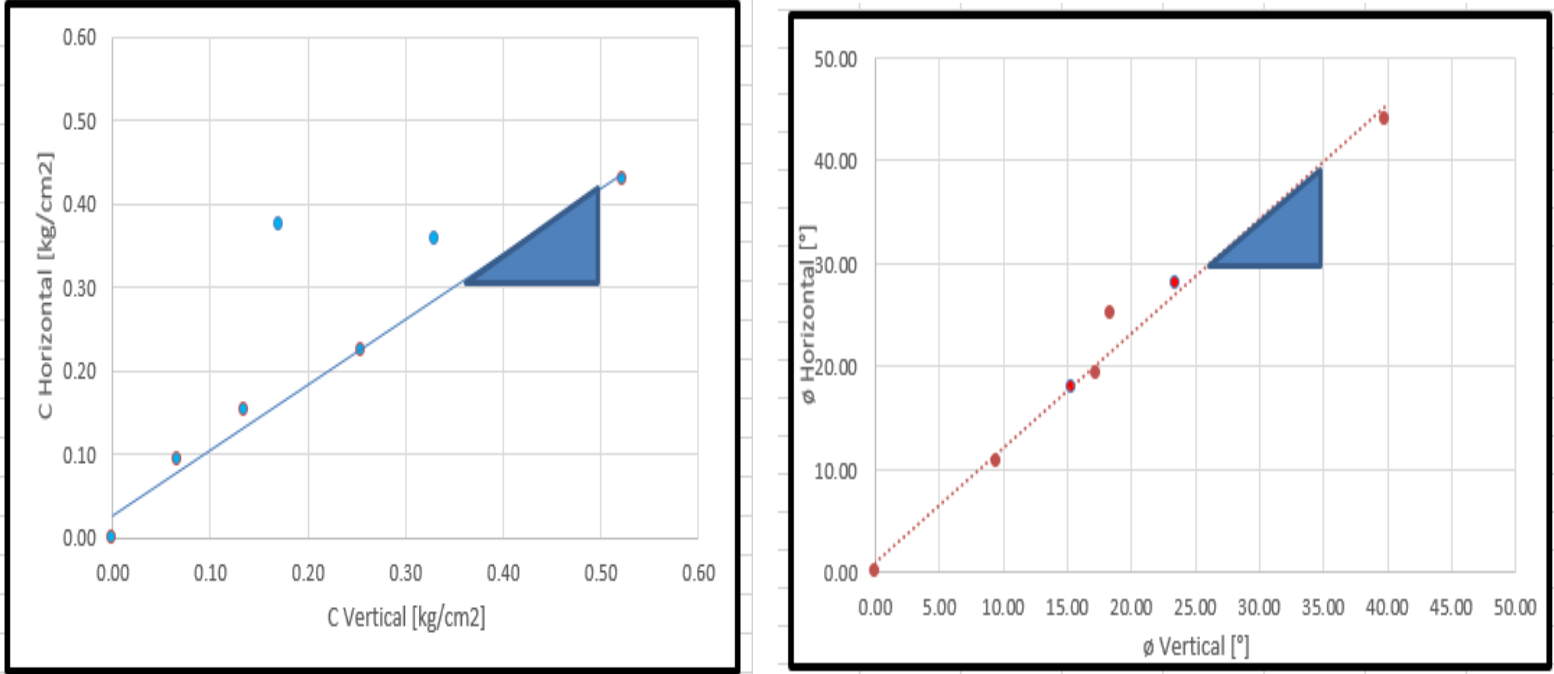

Figure 7. $\mathrm{C}_{\text {Horizontal }} \mathrm{VS} \mathrm{C}_{\text {Vertical }}$

Based on these calculations, this volcanic soil sample shows anisotropy properties.

\subsubsection{Consolidation}

Consolidation testing on $6 \mathrm{x}, 8 \mathrm{x}, 10 \mathrm{x}, 12 \mathrm{x}, 14 \mathrm{x}$, and $17 \mathrm{x}$ ground samples by taking the test sample in the direction of the tilt angle of $0^{\circ}$ (Vertical) soaking and not immersing and $90^{\circ}$ (Horizontal) soaking and not immersing. This sample of volcanic seeds' compressibility is getting more and more crushed, and $\mathrm{Cc}$ and $\mathrm{Cv}$ 's value decreases [23]. The horizontal coefficient of consolidation horizontal $\left(\mathrm{C}_{\mathrm{h}}\right)$ is greater than the vertical $\left(\mathrm{C}_{\mathrm{v}}\right)$. The following are the results of consolidation tests on soil samples in various grinds: 
Table 4. Results of Consolidation

\begin{tabular}{|c|c|c|c|c|c|c|c|c|}
\hline \multirow{3}{*}{ COMPACTION } & \multicolumn{4}{|c|}{ HORIZONTAL } & \multicolumn{4}{|c|}{ VERTICAL } \\
\hline & \multicolumn{2}{|c|}{ UNSATURATED } & \multicolumn{2}{|c|}{ SATURATED } & \multicolumn{2}{|c|}{ UNSATURATED } & \multicolumn{2}{|c|}{ SATURATED } \\
\hline & $\mathbf{C}_{\mathrm{c}}$ & $\mathbf{C}_{\mathbf{V}}$ & $\mathbf{C}_{\mathrm{c}}$ & $\mathbf{C}_{\mathbf{V}}$ & $\mathbf{C}_{\mathrm{c}}$ & $\mathrm{C}_{\mathrm{V}}$ & $\mathbf{C}_{\mathrm{c}}$ & $\mathbf{C}_{\mathbf{V}}$ \\
\hline$(\mathbf{X})$ & - & $\mathrm{cm}^{2} / \mathrm{s}$ & - & $\mathrm{cm}^{2} / \mathrm{s}$ & - & $\mathrm{cm}^{2} / \mathrm{s}$ & - & $\mathrm{cm}^{2} / \mathrm{s}$ \\
\hline 6 & 0.5209 & 0.0090 & 0.6257 & 0.0113 & 0,4454 & 0.0033 & 0.4958 & 0.0052 \\
\hline 8 & 0.4619 & 0.0091 & 0.4849 & 0.0049 & 0,3298 & 0.0041 & 0.3783 & 0.0058 \\
\hline 10 & 0.4620 & 0.0056 & 0.5149 & 0.0089 & 0,3154 & 0.0057 & 0.3458 & 0.0078 \\
\hline 12 & 0.3352 & 0.0076 & 0.4667 & 0.0049 & 0,2353 & 0.0050 & 0.3484 & 0.0054 \\
\hline 14 & 0.4359 & 0.0068 & 0.4584 & 0.0078 & 0,4319 & 0.0038 & 0.3901 & 0.0064 \\
\hline 17 & 0.2559 & 0.0050 & 0.3130 & 0.0103 & 0,4232 & 0.0084 & 0.3899 & 0.0064 \\
\hline
\end{tabular}

Source: Laboratory Testing of the Department of Civil Engineering, Parahyangan Catholic University.

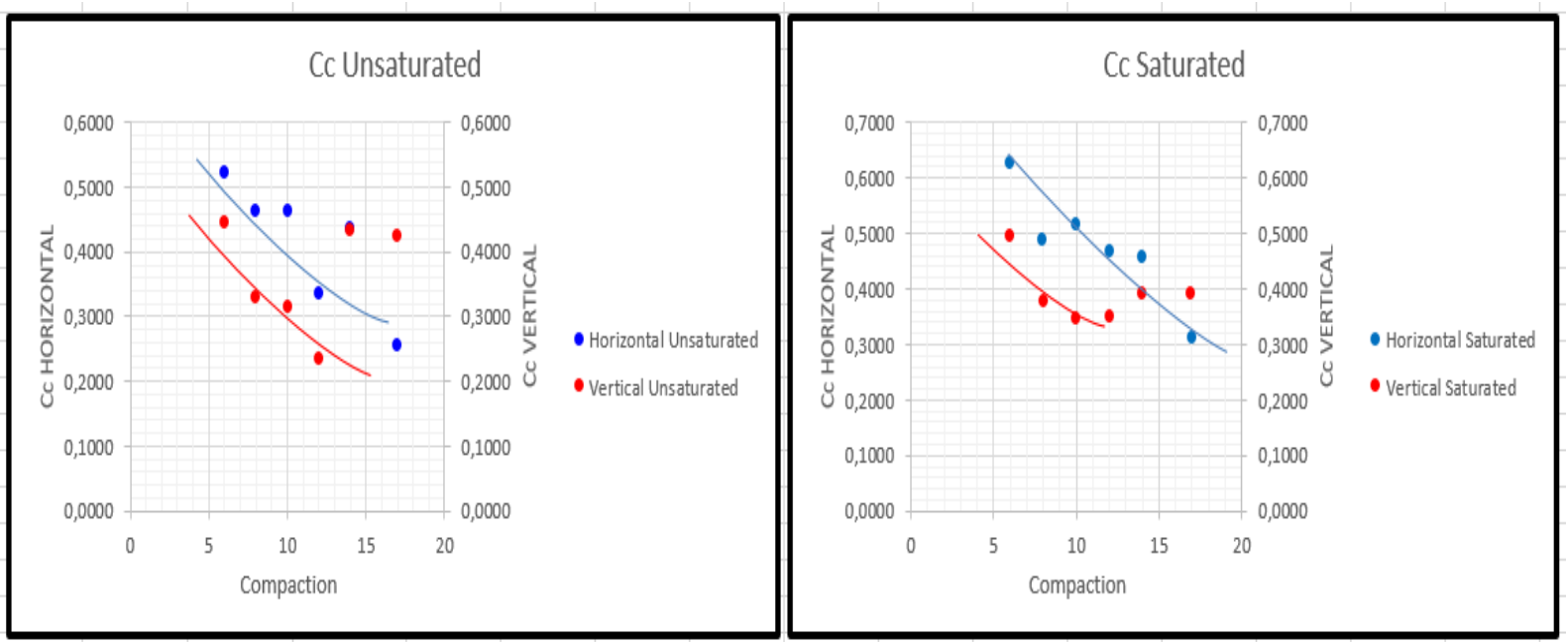

Figure 8. $\mathrm{C}_{\mathrm{c}}$ Unsaturated and $\mathrm{C}_{\mathrm{c}}$ Saturated

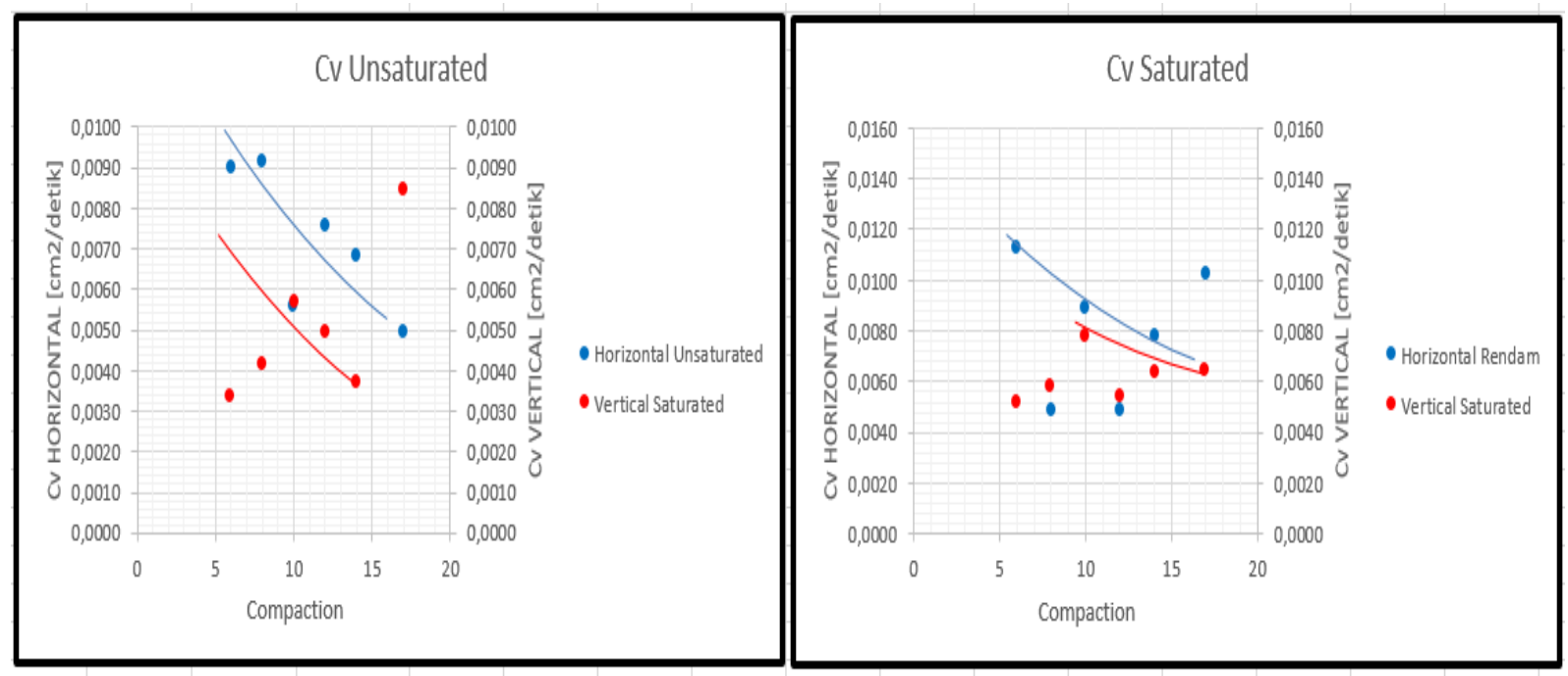

Figure 9. $\mathrm{C}_{\mathrm{v}}$ Unsaturated and $\mathrm{C}_{\mathrm{v}}$ Saturated 
In Figure 8 and Figure 9, the compressibility of this volcanic soil sample, the more grinding it will give the $\mathrm{Cc}$ and $\mathrm{Cv}$ values decreasing. The horizontal $\mathrm{Cc}$ value is greater than the vertical $\mathrm{Cc}$ value and the horizontal $\mathrm{Cc}$ value are greater than the vertical $\mathrm{Cv}$ value.

\subsection{Result CPTu and Dilatometer}

Based on Figure 10, the CPTu test shows a modulus value of $515.56 \mathrm{~kg} / \mathrm{cm}^{2}$. Meanwhile, the dilatometer test results obtained a modulus value of $672.23 \mathrm{~kg} / \mathrm{cm}^{2}$. Based on Figure 10, the horizontal direction's modulus value is greater than in the vertical direction. Based on the CPTu test, the $\mathrm{Cu}$ value was $0.59 \mathrm{~kg} / \mathrm{cm}^{2}$. Meanwhile, from the dilatometer test results, the $\mathrm{Cu}$ value was $0.72 \mathrm{~kg} / \mathrm{cm}^{2}$, so that the horizontal direction of the $\mathrm{C}_{\mathrm{u}}$ value is greater than the vertical direction.

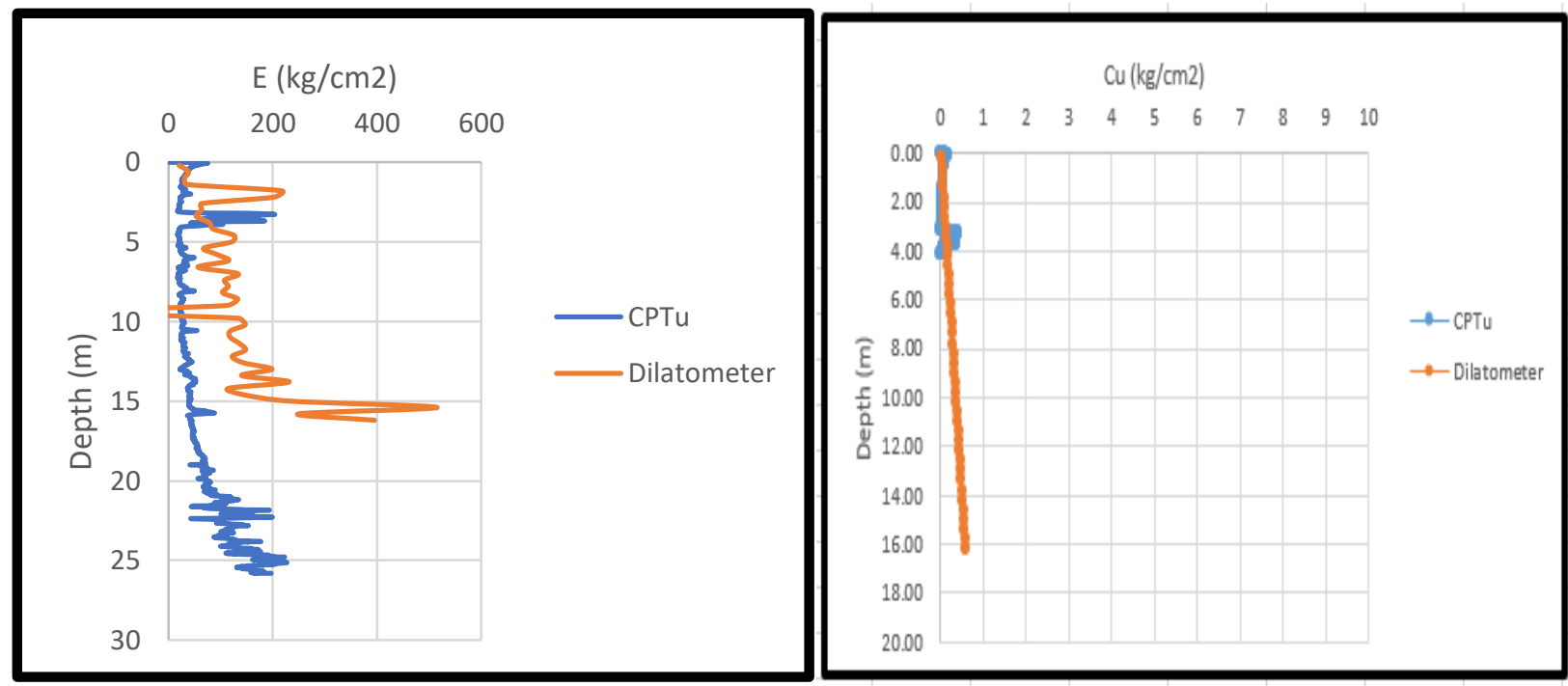

Figure 10. Depth $\mathrm{V}_{\mathrm{x}} \mathrm{E}$ and Depth $\mathrm{V}_{\mathrm{s}} \mathrm{Cu}$ 


\section{Conclusion and Suggestion}

\subsection{Conclusion}

The conclusion from this research that; (1) the volcanic soils in the Theme Park Lido Bogor area are silty clay deposits, anisotropy testing, is done in the field and the laboratory; (2) the CPTu test shows a modulus value was $515.56 \mathrm{~kg} / \mathrm{cm}^{2}$, from the dilatometer test results, the modulus value was $672.23 \mathrm{~kg} / \mathrm{cm}^{2}$; (3) the $C_{u}$ value was $0.59 \mathrm{~kg} / \mathrm{cm}^{2}$, the $C_{u}$ value was $0.72 \mathrm{~kg} / \mathrm{cm}^{2}$; (4) the horizontal shear strength $\left(\mathrm{S}_{\mathrm{uh}}\right)$ is greater than the vertical slope shear strength $\left(S_{\mathrm{uv}}\right)$. In this case, the ratio obtained for shear strength is $S_{\mathrm{uh}}=1.3 \mathrm{~S}_{\mathrm{uv}}$, the horizontal coefficient of consolidation $\left(\mathrm{C}_{\text {horizontal }}\right)$ greater than the consolidation vertical $\left(\mathrm{C}_{\mathrm{vertical}}\right)$.

\subsection{Suggestion}

Further research is needed using different slope orientations to obtain the shear strength of undrained soils in various slope orientations. It is necessary to carry out further studies regarding the ratio of undrained shear strength in vertical and horizontal orientation $\left(\mathrm{S}_{\mathrm{uv}} / \mathrm{S}_{\mathrm{uh}}\right)$ for volcanic Soil. 


\section{References}

[1] B. M. Das, Advenced Soil Mechanics. McGraw - Hill Book Company, Singapore, 1987.

[2] and I. Y. Shoji, S., T. Ito, M. Saigusa, "Properties of nonallophanic Andosols from Japan,” Soil Sci, vol. 140, pp. 264-277, 1985.

[3] K. Effendi A.C, Hermanto B, “Geological Map Sheet Bogor, Java, Center for Geological Research and Development, Bandung.," 1998.

[4] D. W. Apriani, U. Mustofa, and R. Hidayat, "Soil Shear Strength Parameter Analysis Based On Behavior Analysis Of Landslide Case," U KaRsT, vol. 4, no. 2, pp. 163-176, 2020, doi: 10.1016/j.nrjag.2017.12.003.

[5] J. E. and J. K. H. Bowles, Physical and Geotechnical characteristics of Soil (soil mechanics). Jakarta: Erlangga, 1991.

[6] D. W. Apriani, U. Mustofa, and R. Hidayat, "Direct Shear Strength Of Clay Reinforced With Coir Fiber," Ukarst J. Univ. Kadiri Ris. Tek. Sipil, vol. 4, no. 2, pp. 151-162, 2020.

[7] W. D. Holtz, R. D. Kovacs, An Introduction To Geotechnical Engineering. Prentice Hall , New Jersey, 1981.

[8] C. and L. P. van R. Mizota, "Clay mineralogy and chemistry of soils formed in volcanic material in diverse climatic regions. Soil Monograph 2," Wageningen, Netherlands, 1989.

[9] G. Terzaghi, K., Peck R. B. and Mesri, "Soil Mechanics In Engineering Practice,” J. W. \& Sons, Ed. New York, 1996, p. 549.

[10] R. D. Sivakugan, N., Chameau, J. L. and Holtz, ““ “Anisotropy Studies on Cuboidal Shear Device“", ASCE J, Geot. Eng., vol. 119, no. No.6, pp. 973-983, 1993.

[11] M. G. Luteneger , A. Kabir, ““'Interpretation of Piezocone Result in Overconsolidated Clays“"," 1988, pp. 141-146.

[12] J. M. Duncan, "The Effect of Anisotropy and Reorientation of Principal Stresses on the Shear Strength of Saturated Clayle," University of California, 1966.

[13] NL.D.Wesley, Soil Mechanics, IV. Public Works Publishing Agency, 1977.

[14] J. E. Bowles, "Physical and Geotechnical Properties of Soil, ” 2nd ed. Jakarta: Erlangga, 1991.

[15] R. L. and C. W. C. Parfitt, "Estimation of forms of Fe and Al : a review and analysis of contrasting soils by dissolution and Moessbauer methods," Aust. J. Soil Res., no. 26, pp. $121-144,1988$. 
[16] M. Silvestri, V. Aubertin, ““ "Anisotropy and In-Situ Vane Tests, “ Vane Shear Strength Testing in Soils : Field and Laboratory Studies," Philadelphia, 1988.

[17] A. I. Candra, "ANALISIS DAYA DUKUNG PONDASI STRAUSS PILE PADA PEMBANGUNAN GEDUNG MINI HOSPITAL UNIVERSITAS KADIRI,” Ukarst, vol. 1, no. 1, pp. 63-70, 2017.

[18] T.-H. Whittle, Andrew J., DeGroot, Don J., Ladd, Charles C, and Seah, “, ' Model Prediction of Anisotropy Behavior of Boston Blue Clay, ', ,' ASCE J, Geot. Eng., vol. 120, no. No.1, pp. 199-224, 1994.

[19] P. W. Mayne, “Stress Anisotropy Effects on Clay Strength,” ASCE J, vol. 111, no. 1, pp. 355-366, 1985.

[20] P. P. Rahardjo, "Penyelidikan Geoteknik dengan Uji In-situ,” Bandung, 2008.

[21] A. I. Candra, S. Anam, Z. B. Mahardana, and A. D. Cahyono, "Studi Kasus Stabilitas Struktur Tanah Lempung," Ukarst J. Univ. Kadiri Ris. Tek. Sipil, vol. 2, no. 2, pp. 8897, 2018.

[22] J. E. Bowles, “Engineering Properties of Soils and Their Mesurement," 2nd ed. New York: McGraw-Hill Book Company, 1978.

[23] N. C. and R. R. W. Brady, "Elements of Nature and Properties of Soils," Prentice-Hall, Inc. New Jersey, p. 559, 2000. 